\title{
The Diverse Collection of Exotic Tropical Fruits in The Indonesian Tropical Fruit Research Institute (ITFRI)
}

\author{
Fitriana Nasution*1, Sri Hadiati1 \\ ${ }_{1}^{1}$ Indonesian Tropical Fruit Research Institute \\ Jl Raya Solok Aripan, Km 8, Solok, West Sumatra, 27301 Indonesia \\ *Corresponding author: nasution79@gmail.com
}

\section{ARTICLE HISTORY \\ Received : 21 July 2020 \\ Revised : 20 August 2020 \\ Accepted : 24 September 2020}

\section{KEYWORDS}

Exotic;

Tropical;

Fruit;

Collection;

\begin{abstract}
Indonesian Tropical Fruit Research Institute (ITFRI) known as an institute collecting exotic tropical fruits in Indonesia. The present study was carried to evaluate the characters of five exotic fruits in the Indonesian Tropical Fruit Research Institute (ITFRI), Solok, West Sumatra, Indonesia. The experiment used field observation. The characters considered were leaf character (leaf shape, leaf margin, leaf tip, leaf base, the color of upper leaf, color of under leaf, leaf surface, leaf length, leaf width), and fruit character (fruit shape, fruit peel texture, fruit length, fruit width, fruit weight, the color of mature peel, the color of mature flesh, taste, fruit weight, seed weight, seed number). Data were analyzed descriptively using tables. The five exotic fruits' morphological characteristics have demonstrated that every species of fruit has specific characteristics. These fruits have the potential to be raw materials for the pharmacy industry.
\end{abstract}

This is an open-access article under the CC-BY-SA license.

\section{INTRODUCTION}

Asia has more than 70 different fruits; however, there are only about 20 species for large-scale commercial cultivation (Arora \& Rao, 1994). The South-East Asian region is an ideal area to grow fruit crops. The fruits have different appearance, taste, and texture (Yaacob \& Subhadrabandhu, 1995). Fruits are enriched with essential nutrients and low in calorie content. They can increase people's health (Devine, et al., 1998).

Indonesia has many genetic resources. Thirty thousand plants grow in the forest, including exotic fruits; however, only about 4,000 species have been used by people (Uji, 2007). Some of them have the potency to be used in domestication program. The exotic fruits need to maintain because of the economic value as traditional medicine or flavor adding in food (Zurriyati, et al., 2018). Because some exotic fruits have almost gone extinct, people need to conserve these fruits. Conservation strategies involve cultural aspects, socio-economic, and plant diversity (Gulati, 2018). Education and tourism are objectives of plant diversity conservation (Hutabarat \& Wilkie, 2018).

Indonesian Tropical Fruit Research Institute (ITFRI) collects exotic tropical fruits in Indonesia. The present study was carried to evaluate the characters of five exotic fruits in the Indonesian Tropical Fruit Research Institute (ITFRI), Solok, West Sumatra, Indonesia.

\section{MATERIALS AND METHODS}

The research was carried out at Indonesian Tropical Fruit Research Institute (ITFRI), Aripan experimental site, Solok, West Sumatra, Indonesia, from January 2012 to December 2014. The experiment used field observation. The characters considered were leaf character (leaf shape, leaf margin, leaf tip, leaf base shape, the color of upper leaf, color of under leaf, leaf surface, leaf length, leaf width), and fruit character (fruit shape, fruit peel texture, fruit length, fruit width, fruit weight, the color of mature peel, the color of mature flesh, taste, fruit weight, flesh thickness, seed weight, seed number). Data collected were analyzed descriptively using tables.

\section{RESULTS AND DISCUSSIONS}

\subsection{Fruit Collection}

\section{a. Diospyros blancoi}

Diospyros blancoi belongs to the Ebenaceae of Ericales family. The fruit is eaten fresh. Its wood is used for carving (Jensen, 2008). Verheij \& Coronel (1992) noted that this tree has some vernacular names, i.e., hong nhung (Indo-China); marit (Thailand); mabolo, kamagong, tabang (Philippines); buah lemak, buah mentega 
(Malaysia); buah mentega, bisbol, mabolo (Indonesia); Mabolo, velvet apple (En); Pommier velours (Fr). The leaf shape is oblong with a length of $22-28.5 \mathrm{~cm}$ and a width of $7.6-10.0 \mathrm{~cm}$. The leaf color is green (Table 1). Putri \& Chiknawati (2016) informed that the leaf is dark green in a mature step. The fruit weight is 236.7 - 399.93 grams (Table 2). The fruit varies greatly at different times. Hung, et al. (2015) recorded that the fruit's size depends on the time it is harvested.

The leaf has the potential to be a raw material for the pharmacy industry. The leaf extract has antioxidant compounds. It can function as an antidiabetic because it can reduce blood glucose (Demetillo, et al., 2018). The leaf extract has antimicrobial properties (Howlader, et al., 2012). The fruit shape is globose with a strong odor or unpleasant aroma (Pobar, 2003). Hung, et al. (2016) found that $D$. blancoi contains 39 different volatile aromas; esters and $\alpha$-farmese are the important aroma compounds.

\section{b. Eugenia uniflora}

Eugenia uniflora is a tree in the family Myrtaceae. This plant is called Brazil cherry. It is a nutritious fruit growing in the tropics and sub-tropics areas (Griffis, et al., 2009). The leaf characteristics are smallness (1.8-2.5 x 2.1-2.5 $\mathrm{cm})$, ovate, and a glossy surface. The fruit weight of $E$. uniflora is 5.1-9.6 grams and red with 1-3 seeds (Table 1). The pulp juice is sweet-acid. It can function as a raw material for commercial products, such as jellies, jams, desserts, and juices (Griffis, et al., 2008). The pulp has the potential to be food colorants (Borges, et al., 2016).

E. uniflora has biological activities as a medicinal plant. The fruit extract has the potential to function as an antioxidant and antidepressant because it against metabolic alteration (Oliveira, et al., 2017). The leaf extract has phenolic content (Bakr, et al., 2017; Ramos, et al., 2017), flavonoids (Rattmann, et al., 2012), anti-inflammatory, antibacterial properties (Falcao, et al., 2018), antioxidant (Migues, et al., 2018). The ripe fruit has analgesic properties (Ogugofor, 2018.).

\section{c. Pometia pinnata}

Pometia pinnata belongs to the family Sapindaceae. The leaf is elliptical and large (28.3 - $36.5 \mathrm{~cm} \times 8.6-11.1 \mathrm{~cm})$ (Table 1). The leaf is suitable for ants' habitat because the tree provides leaf domestic and food (Moog, et al., 2008). The pulp flavor of Pometia pinnata is sweet, TSS value is $9.8-31.2^{\circ}$ Brix (Furay, et al., 2019).

The fruit of Pometia pinnata commonly used as a traditional medicine. The flesh contains tannins, phenolic and steroid. It can be antioxidant agents (Irawan, et al., 2017). The extract of fruit peel has antioxidant properties (Faustina \& Santoso, 2014). The leaf extract can decrease blood pressure (Purwidyaningrum et al., 2017). The stem bark contains triterpenoid (Trimedona, et al., 2015). The fruit has a seed that can function as a medicine for diabetes since it has anti-diabetic properties (Sukiman, et al., 2018).

\section{d. Cynometra cauliflora}

Cynometra cauliflora is a plant in the family Fabaceae. $C$. cauliflora (namnam) is a small or shrub tree. The fruit shape is kidney shape, and the taste is sour (Table 2). It is suitable for salad (Verheij \& Coronel, 1992). The composition of Cynometra cauliflora per $100 \mathrm{~g}$ edible portion is moisture $87.27 \%$, ash $1.41 \%$, protein $0.66 \%$, fat $0.18 \%$, fiber $1.72 \%$, carbohydrate $8.77 \%$. The mineral content in Cynometra cauliflora per $100 \mathrm{~g}$ samples is calcium $6.14 \mathrm{mg}$, zinc $0.48 \mathrm{mg}$, iron $1.01 \mathrm{mg}$, natrium 0.55 mg (Rabeta \& Faraniza, 2013).

The tree is an underutilized fruit, but it has medicinal values. The fruit can function as a cytotoxic to cure the human promyelocytic leukemia (Tajudin, et al., 2012). The leaf extract can function as an antibacterial agent (Abd. Wahab, et al., 2019; Ulpiyah, et al., 2019) and antioxidant (Ado, et al., 2013). Those components are useful in the pharmacy industry or drug formulations.

\section{e. Manilkara kauki}

Manilkara kauki belongs to the family Sapotaceae. The leaf shape is obovate $(7.7-9 \mathrm{~cm} \times 5.9-4.9 \mathrm{~cm})$. The leaf color is yellow-green group $148 \mathrm{C}$. Fruit shape is ellipsoid, medium $(2.9-3.3 \mathrm{~cm} \times 2.2-2.8 \mathrm{~cm})$, and the taste is slightly sweet (Table 1 and 2). This plant can be a roadside tree (Sarwadi, et al., 2018), and it can be an herb. The leaf extract contains polyprenol and dolichol (Basyuni \& Wati, 2018). 


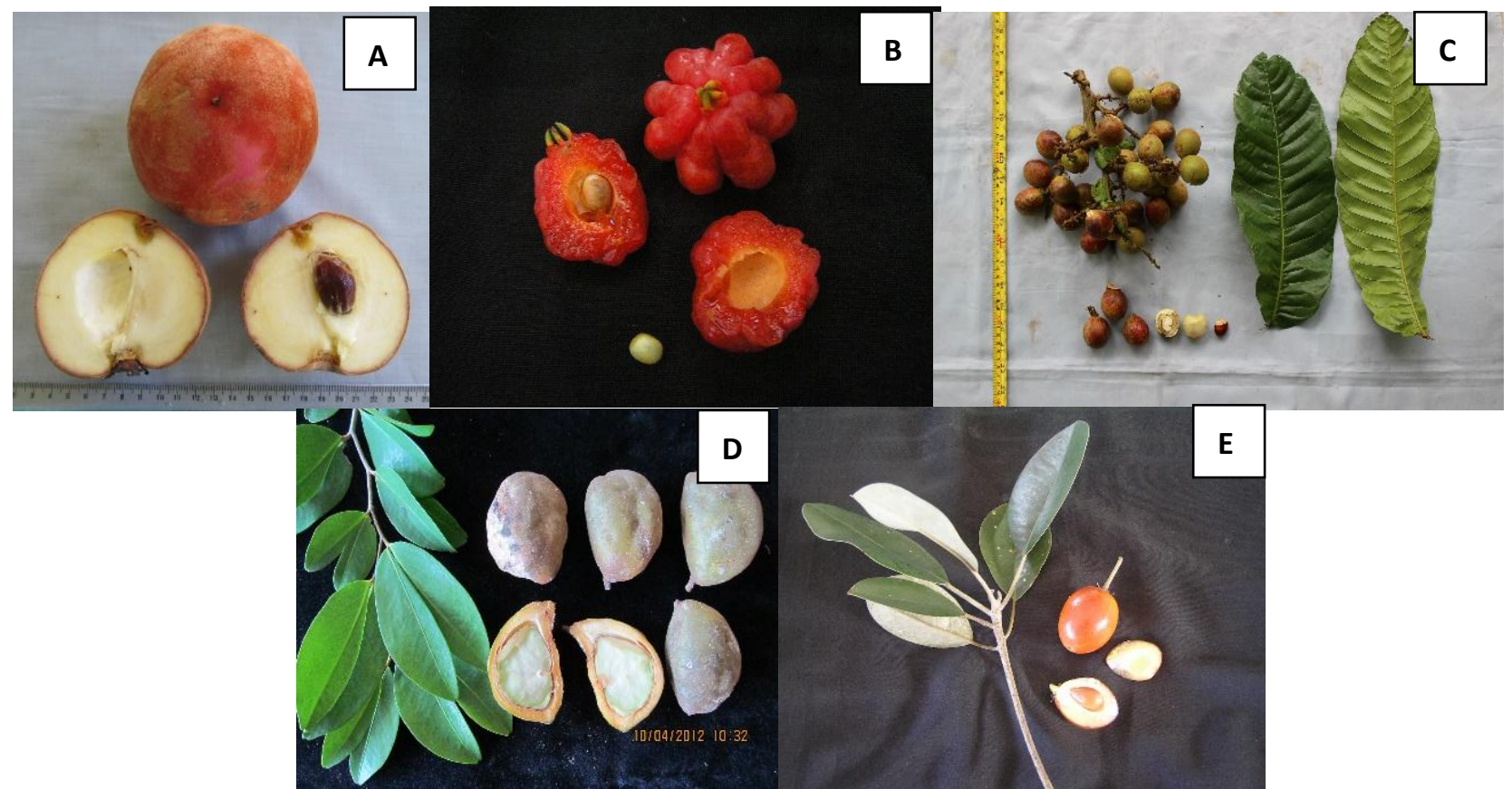

Figure 1. The appearance of five exotic fruits (A. Diospyros blancoi, B. Eugenia uniflora, C. Pometia pinnata, D. Cynometra cauliflora, E. Manilkara kauki).

\subsection{Morphological Characters of Collected Fruits}

Table 1. Leaf character

\begin{tabular}{llllll}
\hline Leaf Character & $\begin{array}{l}\text { Diospyros } \\
\text { blancoi }\end{array}$ & $\begin{array}{l}\text { Eugenia } \\
\text { uniflora }\end{array}$ & $\begin{array}{l}\text { Pometia } \\
\text { pinnata }\end{array}$ & Cynometra cauliflora & $\begin{array}{c}\text { Manilkara } \\
\text { kauki }\end{array}$ \\
\hline $\begin{array}{l}\text { Leaf shape } \\
\text { Leaf margin }\end{array}$ & Oblong & Ovate & Elliptical & Ovate-oblong & Obovate \\
$\begin{array}{l}\text { Leaf tip } \\
\text { Eeaf base }\end{array}$ & Acute & Entire & Sinuate & Entire & Entire \\
$\begin{array}{l}\text { Color of the } \\
\text { upper leaf }\end{array}$ & Green N137A & Green N137B & Green N 137 D & Green group N 137 A & Acute \\
$\begin{array}{l}\text { Color of under } \\
\text { leaf }\end{array}$ & Green 137D & Green 138 B & Green 137 C & Green group N 137 D N 137 A & Yellow-green group \\
Leaf surface & Shiny & Glossy & Shiny & Glossy & Acute \\
Leaf length $(\mathrm{cm})$ & $22-28.5$ & $2.9-7.1$ & $28.3-36.5$ & $5.9-8$ & Glossy \\
Leaf width $(\mathrm{cm})$ & $7.6-10.0$ & $1.3-3.8$ & $8.6-11.1$ & $2.2-3.1$ & $7.7-9$ \\
\hline
\end{tabular}

Table 2. Fruit character

\begin{tabular}{llllll}
\hline Fruit Character & $\begin{array}{l}\text { Diospyros } \\
\text { blancoi }\end{array}$ & Eugenia uniflora & $\begin{array}{l}\text { Pometia } \\
\text { pinnata }\end{array}$ & $\begin{array}{l}\text { Cynometra } \\
\text { cauliflora }\end{array}$ & $\begin{array}{l}\text { Manilkara } \\
\text { kauki }\end{array}$ \\
\hline Fruit shape & Globose & Globose & Ellipsoid & Kidney & Ellipsoid \\
Fruit peel texture & hairy & Soft & Soft & Rugose & Shiny \\
Fruit length (cm) & $7.75-8.7$ & $1.8-2.5$ & $2.88-3.27$ & $4.36-5.04$ & $2.9-3.3$ \\
Fruit width (cm) & $8.27-9.12$ & $2.1-2.5$ & $2.51-3.12$ & $3.19-3.48$ & $2.2-2.8$ \\
Fruit Weight (g) & $236.7-399.93$ & $5.1-9.6$ & $15.3-20.84$ & $16.79-25.43$ & $9.7-13.01$ \\
Color of mature & Orange-red & Red group 44 A & Purple group & Yellow-green group & Orange-red group 33 B \\
peel & 34A & & N77A & 152 A & Yellow- white group \\
Color of mature & White 155A & Red group 44 A & Yellow- white & Yellow group 11 C & 158 D \\
flesh & Slightly sweet & Sour & 158 B & Sour & Slightly sweet \\
Taste & 33.95-50.9 & $4.4-7.8$ & $5.2-6.53$ & $5.51-6.25$ & $1.5-3.1$ \\
Seed weight (g) & $1-8$ & $1-3$ & 1 & 1 & $2-4$ \\
Number of seeds & & & & \\
\hline
\end{tabular}





\section{CONCLUSION}

Indonesian Tropical Fruit Research Institute (ITFRI) collects exotic fruits to ensure that endangered are conserved. The result of the five exotic fruits' morphological characteristics demonstrated that every species of fruit has specific characteristics. They have the potential to be raw materials in the drug pharmacy. Hence, it needs more observation to determine the utilization of these fruits in the future, whether as traditional medicine or as edible fruit.

\section{REFERENCES}

Abd Wahab, N. Z., Badya, N., Ibrahim, N., \& Kamarudina, M. K. A. (2019). Phytochemistry and Antibacterial Activity of Cynometra Cauliflora. Indian Journal of Public Health Research \& Development, 10(4).

Ado, M. A., Abas, F., Ismail, I. S., Ghazali, H. M., \& Shaari, K. (2015). Chemical profile and antiacetylcholinesterase, antityrosinase, antioxidant and $\alpha$-glucosidase inhibitory activity of Cynometra cauliflora L. leaves. Journal of the Science of Food and Agriculture, 95(3), 635-642. https://doi.org/10.1002/jsfa.6832.

Arora, R. K., \& Ramanatha Rao, V. (1994). Expert Consultation on Tropical Fruit Species of Asia. Proceedings of Expert Consultation on Tropical Fruit Species of Asia, 17-19.

Bakr, R. O., Mohamed, S. A., \& Waly, N. E. (2017). Phytochemical and biological investigation of Eugenia uniflora L. cultivated in Egypt. Journal of Pharmacognosy and Phytotherapy, 9(5), 57-66. https://doi.org/10.5897/JPP2017.0443.

Basyuni, M., \& Wati, R. (2018, November). Polyisoprenoids profile and composition from selected plant Sapotaceae family. In IOP Conference Series: Materials Science and Engineering (Vol. 434, p. 012104).

Borges, K. C., Bezerra, M. D. F., Rocha, M. P., Silva, E. S. D., Fujita, M. I., Genovese, A., \& Correia, R. P. (2016). Fresh and spray dried pitanga (Eugenia uniflora) and jambolan (Syzygium cumini) pulps are natural sources of bioactive compounds with functional attributes. Journal of Probiotics \& Health, 4(2), 1-8.

Demetillo, M. T., Nuñeza, O. M., Uy, M. M., \& Senarath, W. T. P. S. K (2018).. Phytochemical Screening, Antioxidant and Antidiabetic Evaluation of Leaf Extracts from Diospyros blancoi A. D.C. International Journal of Pharmaceutical Sciences and Research. 10 (8): 3951-3956.

Devine, C. M., Connors, M., Bisogni, C. A., \& Sobal, J. (1998). Life-course influences on fruit and vegetable trajectories: qualitative analysis of food choices. Journal of Nutrition Education, 30(6), 361-370. https://doi.org/10.1016/S0022-3182(98)70358-9.

Falcão, T. R., de Araújo, A. A., Soares, L. A. L., de Moraes Ramos, R. T., Bezerra, I. C. F., Ferreira, M. R. A., ... \& de Medeiros, J. S. (2018). Crude extract and fractions from Eugenia uniflora Linn leaves showed anti-inflammatory, antioxidant, and antibacterial activities. BMC complementary and alternative medicine, 18(1), 84.

Faustina, F. C., \& Santoso, F. (2014). Extraction of fruit peels of Pometia pinnata and its antioxidant and antimicrobial activities. J. Pascapanen, 11(2), 80-88.

Furay, A., Ahmad, U., \& Widodo, S. (2019, June). Study on Quality Parameters of Yellow Matoa Fruit (Pometia pinnata) Using Digital Image Processing. In IOP Conference Series: Materials Science and Engineering (Vol. 557, No. 1, p. 012025). IOP Publishing.

Griffis, Jr, J. L., McDonald, T. G., Smith, V. E., \& Manners, M. M. (2008, March). Eugenia uniflora: a nutritious, easy-to grow fruit for the tropics. In International Symposium on Underutilized Plants for Food Security, Nutrition, Income and Sustainable Development 806 (pp. 277-284).

Gulati, R. (2018). Strategies for sustaining plant germplasm evaluation and conservation-a review. Life Sci Inform, 4, 313-320. doi:10.26479/2018.0405.25.

Howlader, M. S. I., Sayeed, M. S. B., Ahmed, M. U., Mohiuddin, A. K., Labu, Z. K., Bellah, S. F., \& Islam, M. S. (2012). Characterization of chemical groups and study of antioxidant, antidiarrhoeal, antimicrobial and cytotoxic activities of ethanolic extract of Diospyros blancoi (Family: Ebenaceae) leaves. J Pharm Res, 5(6), 3050-3052.

Hung, S. F., I. Z. Chen, and S. F. Roan. (2015). Preliminary results of fruit selection and induced parthenocarpy of mabolo (Diospyros blancoi A. Dc.). Genet Resour Crop Evol. 62: 1127-1134.

Hung, S. F., Roan, S. F., Chang, T. L., King, H. B., \& Chen, I. Z. (2016). Analysis of aroma compounds and nutrient contents of mabolo (Diospyros blancoi A. DC.), an ethnobotanical fruit of Austronesian Taiwan. journal of food and drug analysis, 24(1), 83-89. https://doi.org/10.1016/j.jfda.2015.08.004.

Hutabarat, P. W., \& Wilkie, P. (2018). The Sapotaceae of Indonesia and the Potential Role of Botanic Gardens in their Conservation. Sibbaldia: the Journal of Botanic Garden Horticulture, (16), 141-154. https://doi.org/10.23823/Sibbaldia/2018.252.

Irawan, C., Hanafi, L. S., \& Henny, R. (2017). Phytochemistry and total phenolic content of methanol extract of Pometia pinata JR Forst. \& G. Forst. fruit flesh from Papua, Indonesia. Tropical Plant Research, 4(3), 401-404.

Jensen, M. (2001). Trees and fruits of Southeast Asia. Orchid Press.

Migues, I., Baenas, N., Gironés-Vilaplana, A., Cesio, M. V., Heinzen, H., \& Moreno, D. A. (2018). Phenolic profiling and antioxidant capacity of Eugenia uniflora L.(Pitanga) samples collected in different uruguayan locations. Foods, 7(5), 67. https://doi.org/10.3390/ foods7050067.

Moog, J., Atzinger, K., Hashim, R., \& Maschwitz, U. (2008). Do tenants always pay their rent? The Asian ant-plant Pometia pinnata (Sapindaceae) and its leaf domatia provide free access to generalist ants. Asian Myrmecol, 2, 17-32.

Oliveira, P. S., Chaves, V. C., Bona, N. P., Soares, M. S. P., de Souza Cardoso, J., Vasconcellos, F. A., ... \& Gamaro, G. D. (2017). Eugenia uniflora fruit (red type) standardized extract: a potential pharmacological tool to diet-induced metabolic syndrome damage management. Biomedicine \& pharmacotherapy, 92, 935-941. https://doi.org/ 10.1016/j.biopha.2017.05.131.

Ogugofor, M. O. (2018). Evaluation of the Nutritional Compositions and Analgesic Effects of the Flavonoid Fraction of Eugenia uniflora Ripe Fruit Pulp. American Journal of Ethnomedicine, 5(1), 7.

Pobar, R. (2003). Enhancing the use of value-added products from underutilized fruit of the endangered mabolo (Diospyros blancoi) tree. International Journal of Environmental and Rural Development, 4(1), 100-105.

Purwidyaningrum, I., Sukandar, E. Y., \& Fidrianny, I. R. D. A. (2017). Antihypertensive activity of extract and fractions of matoa (Pometia Pinnata J. R \& G forts) leaves. Asian J Pharm Clin Res, 10(3), 323-328.

Putri, E. K., \& Chikmawati, T. (2016). Leaf flushing as taxonomic evidence of some Diospyros species. Floribunda, 5(2): 31-47. http://dx.doi.org/10.32556/floribunda.v5i2.2015.127.

Rabeta, M. S., \& Faraniza, R. N. (2013). Total phenolic content and ferric reducing antioxidant power of the leaves and fruits of Garcinia atrovirdis and Cynometra cauliflora. International Food Research Journal, 20(4).

Ramos, R. T., Bezerra, I. C., Ferreira, M. R., \& Soares, L. A. L. (2017). Spectrophotometric quantification of flavonoids in herbal material, crude extract, and fractions from leaves of Eugenia uniflora Linn. Pharmacognosy research, 9(3), 253. doi: 10.4103/pr.pr_143_16.

Rattmann, Y. D., de Souza, L. M., Malquevicz-Paiva, S. M., Dartora, N., Sassaki, G. L., Gorin, P. A., \& Iacomini, M. (2012). Analysis of flavonoids from Eugenia uniflora leaves and its protective effect against murine sepsis. Evidence-Based Complementary and Alternative Medicine, 2012. https://doi.org/10.1155/2012/623940.

Sarwadi, A., Irwan, S. N. R., Utami, R. N., \& Raya, A. B. (2019, November). Study on roadside greenery in Yogyakarta City towards development of productive urban landscape. In IOP Conference Series: Earth and Environmental Science (Vol. 361, No. 1, p. 012008). IOP Publishing.

Sukiman, M., Jenny, A. M., Irawan, C., \& Sulistiawaty, L. (2018). Evaluation of antidiabetes activity of matoa seed extract (Pometia pinnata) using enzym $\alpha$-glucosidase. The Pharma Innovation, 7(5, Part A), $10-12$.

Tajudin, T. J. S. A., Mat, N., Siti-Aishah, A. B., Yusran, A. A. M., Alwi, A., \& Ali, A. M. (2012). Cytotoxicity, antiproliferative effects, and apoptosis induction of methanolic extract of Cynometra cauliflora Linn. whole fruit on human promyelocytic leukemia HL-60 cells. Evidence-Based Complementary and Alternative Medicine, 2012. https://doi.org/10.1155/2012/127373.

Trimedona, N., Nurdin, H., Darwis, D., \& Efdi, M. (2015). Isolation of triterpenoid from stem bark of Pometia pinnata, Forst \& Forst. 
Journal of Chemical and Pharmaceutical Research, 7(11), 225-227.

Uji, T. (2007). Keanekaragaman jenis buah-buahan asli Indonesia dan potensinya. Biodiversitas, 8(2):157-167.

Ulpiyah, Z., Shita, A. D. P., \& Wahyukundari, M. A. (2019). Inhibition of namnam (Cynometra cauliflora L.) leaves extract on the growth of Porphyromonas gingivalis. Padjadjaran Journal of Dentistry, 31(2), 106-111. https://doi.org/10.24198/pjd.vol31no2.18540.

Verheij, E. W. M. Plant Resources of South-East Asia No. 2: edible fruits and nuts/ed by EWM Verheij y RE Coronel (No. Libro 634.0958
V39.).

Yaacob, O., \& Subhadrabandhu, S. (1995). The production of economic fruits in South-East Asia. Oxford University Press.

Zurriyati, Y., Riau, L. P. T. P. L. K., Dahono, D., \& Riau, L. P. T. P. L. K. (2018).

Keragaman Sumber Daya Genetik Tanaman Buah-buahan Eksotik di Kabupaten Bintan, Provinsi Kepulauan Riau. Bul. Plasma Nutfah, 22(1), 11-20. 